\title{
Yield Gap Analysis of Mulberry Sericulture in Northwest India
}

\author{
Narendra Kumar Bhatia ${ }^{1 *}$ Mohammad Yousuf $^{2}$, and Raman Nautiyal ${ }^{3}$ \\ ${ }^{I}$ Regional Sericultural Research Station, Central Silk Board, Ministry of Textiles, Govt. of India, Sahaspur- 248196, Dehradun, Uttrakhand, \\ India \\ ${ }^{2}$ Forest Entomology Division, Forest Research Institute, New Forest - 248006, Dehradun (Uttarakhand), India \\ ${ }^{3}$ Forestry Statistics Division, Indian Council of Forestry Research and Education, Ministry of Environment and Forest, Forest Research \\ Institute, New Forest, Dehradun, Uttarakhand, India
}

\section{Abstract}

At the interface of reducing agricultural income and increasing unemployment in agrarian economy of rural India, this article summarizes and evaluates the state of mulberry sericulture in northwest India, which includes Himachal Pradesh, Punjab, Rajasthan, Uttarakhand, and Uttar Pradesh. In $11^{\text {th }}$ plan period (2007-2012), there was an addition of 6196 ha $(217.09 \%)$ of mulberry acreage at annual linier growth rate of $33.44 \%$. However, total silk production could increase only by $54.64 \mathrm{MT}(78.57 \%)$ at annual linier growth rate of $15.59 \%$, due to $43.93 \%$ $(10.82 \mathrm{~kg} / \mathrm{ha})$ reduction in silk productivity at negative growth rate of $-13.46 \%$, annually. And now, average raw silk productivity in north-western states of India remains at $13.81 \mathrm{~kg} / \mathrm{ha}$, which is lower by $452.93 \%(76.36 \mathrm{~kg})$ in comparison to the national average of $100.90 \mathrm{~kg} / \mathrm{ha}$. Paper summaries the reasons for increasing cocoon yield gap at farmer's level and discuss the ways and means to increase raw silk productivity to improve the livelihood delivery of mulberry sericulture in northwest India.

(C) 2013 The Korean Society of Sericultural Sciences

Int. J. Indust. Entomol. 27(1), 131-141 (2013)

Received : 29 Jun 2013

Received : 26 Sep 2013

Accepted : 26 Sep 2013

Keywords:

Seri-business, sericulture extension, Livelihood, Bivoltine silk, Silkworm breeds

\section{Introduction}

In India, 69\% of the population lives in rural area and depends on agriculture for their livelihood. However, according to the National Sample Survey (NSS) published in 2012, the growth rate of employment in agriculture sector has declined from $69 \%$ to $55 \%$ and 70 million people in rural India are without employment. Further, $40 \%$ people in rural area want to leave agriculture, if they get better livelihood option (Gautam and Bhardwaj. 2013), because Indian agriculture have certain constraints like limited cash returns, low per capita availability of cultivable land, monsoon dependency, seasonality effect etc. Given both the on-farm and off-farm employment potential, sericulture industry can nullify the seasonality effect in agriculture.

Sericulture in India is an indispensible part of tradition and as an exclusive craft; it holds a unique distinction in traditional knowledge and societal evolution of poor communities in rural areas. Innovations in sericulture technology have improved silk

\section{*Corresponding author.}

Narendra Kumar Bhatia

Regional Sericultural Research Station, Central Silk Board, Ministry of Textiles, Govt. of India, Sahaspur- 248196, Dehradun, Uttrakhand, India

Tel: +919456541542 / FAX: +911352697383

E-mail: nkb1123@rediffmail.com 


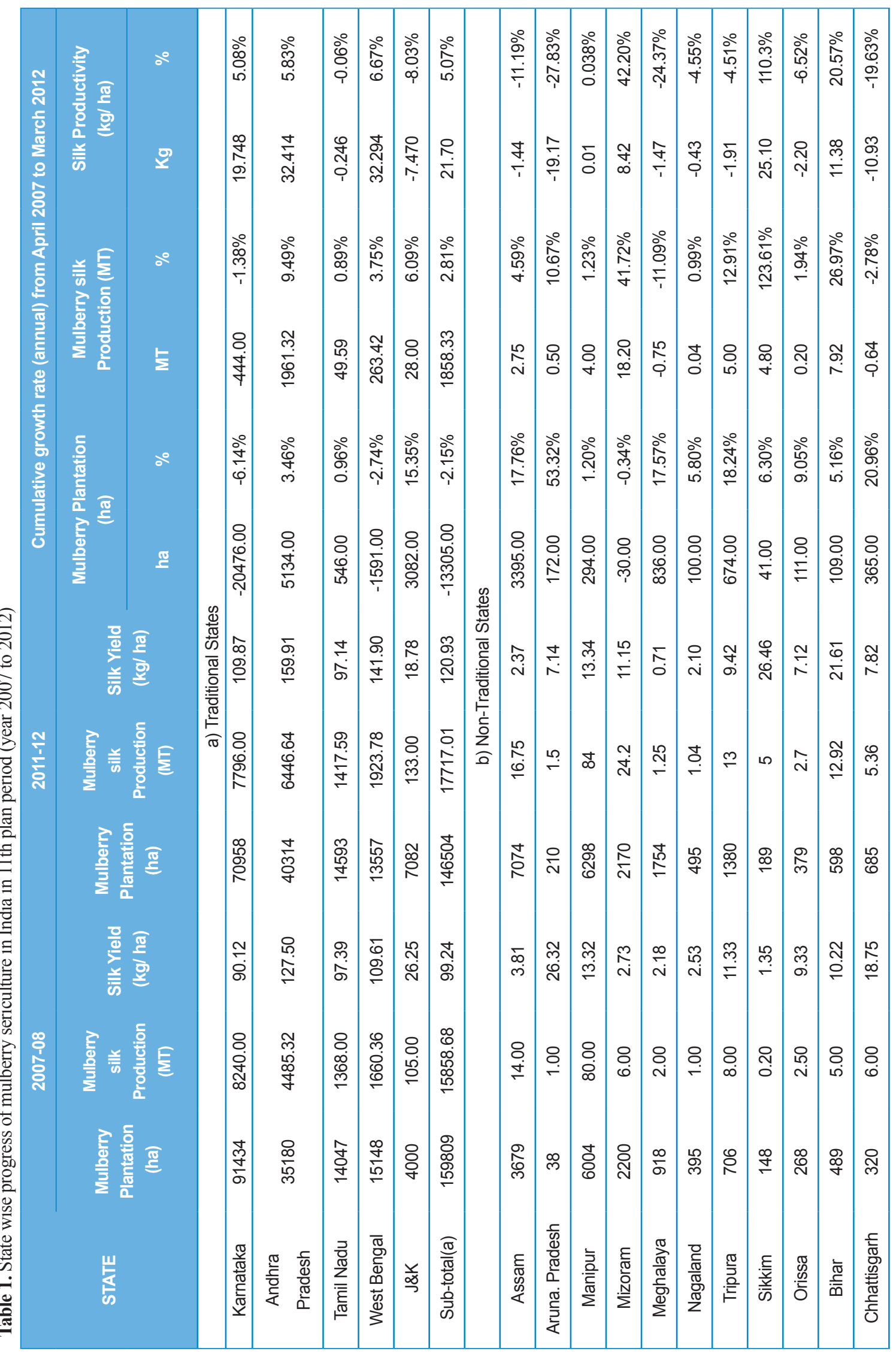




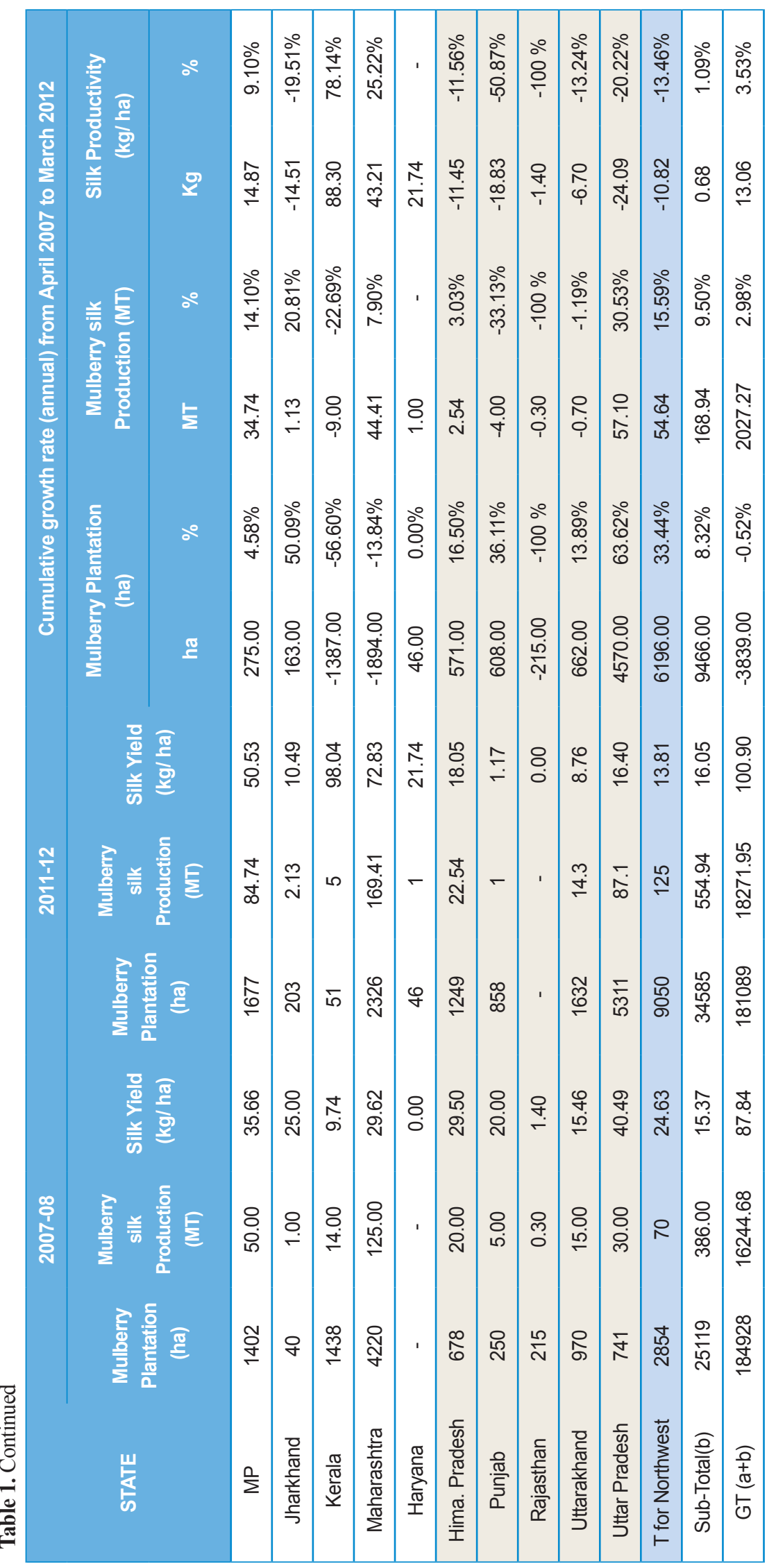


productivity at national level, but their impact in northwest India has been quite uneven. Per hectare raw silk productivity in India has increased from $87.84 \mathrm{~kg} / \mathrm{ha}$ in 2007 to $100.90 \mathrm{~kg} / \mathrm{ha}$ in 2012, but in northwest non-traditional states, which includes Himachal Pradesh, Punjab, Rajasthan, Uttarakhand and Uttar Pradesh, it has reduced to $13.81 \mathrm{~kg} / \mathrm{ha}$ in 2012 from $24.63 \mathrm{~kg} / \mathrm{ha}$ in 2007 (Table 1). As a result, reduced farmer income has decelerated the proliferation process of sericulture industry and has increased the burden of silk import to meet out increasing domestic demand.

Analysis of productivity in sericulture has vast dimension; however, in sericulture yield-gap-analysis, we generally measure the determinants of yield gap. The findings of such research are used in policy formulation to alleviate constraints of low cocoon productivity at national as well as regional level. Conceptually, there are two types of cocoon yield gap in sericulture: Yield gap1 and Yield gap-2. Yield gap-1 indicates the gap between potential cocoon yield of a sericulture research station and the cocoon yield of a demonstration plot. Yield gap 1 is mainly attributed to differences in the locality factors (soil, slope, aspect, moisture regime, climatic deviations, etc) and to non-transferable part of technology. However, yield gap-2 deals with the difference between potential cocoon yield of a demonstration plot and the cocoon yield at farmer's level. Yield gap-2 is very common, and mostly arises when sericulture farmers use inappropriate technology, apply low inputs, and face managerial constraints, besides physical and socio-economic constraints affecting the farming community.

In traditional silk producing states of India, quite a number of studies have been undertaken on trends, profitability, and cocoon yield gap analysis in one form or other (Kumaresan et al., 2005; Lakshmanan et al. 1996; Lakshmanan, 2007; Prakash and Dandin, 2005; Raveendra et al., 1993; Raveendra et al., 1997; Raveendra et al., 2009; Sinha et al. 1985). However, no such study has been undertaken in mulberry sector of northwest India. In the present study, we are dealing with yield gap-2 analysis in mulberry sericulture of northwest India, where productivity enhancement is the last option for sustainability of sericulture. This study gives insights about underlying reasons for the low cocoon productivity and discusses the ways and means to improve it, and accordingly, specific objectives of the study are:

a) Trends analysis of mulberry sericulture in northwest India; and

b) To identify the constraints of cocoon yield gap-2 and to find out viable measures to reduce it.

\section{Background information of Sericulture}

Commercial silk producing insects of order Lepidoptera are classified into mulberry and non-mulberry or Vanya silk. Mulberry silkworm, Bombyx mori L. is a monophagous insect, where larvae feed on mulberry leaves to produces silk cocoon for production of mulberry silk. In 2011-12, mulberry silk contributed $79.2 \%(18,272 \mathrm{MT})$ of the total silk production (23,060 MT) in India (CSB, 2012). In non mulberry sector, Vanya silkworms includes tropical tasar or Indian tasar silkworm, Antheraea mylitta Drury, temperate oak tasar, Antheraea proyeli J., muga silkworm, Antheraea assama Ww, wild eri silkworm, Samia cynthia Drury and domesticated eri silkworm Samia cynthia ricini. All these forest silkworms are polyphagous in nature that constitutes a significant component of faunal diversity in forest ecosystem.

On the demand and supply front, India is the second largest producer of silk in the world next to the China (104, $000 \mathrm{MT})$, but shares only $17.5 \%(23,060 \mathrm{MT})$ of the global raw silk production (131,479 MT). In India, there is a deficit of 5,700 MT raw silk between demand (28,760 MT) and supply (23,060 MT), which is largely imported from China. Projected growth of raw silk production in India is about $4.5 \%$ for $2010-2015$ and $5.0 \%$ for 2015-20; however, demand of silk is expected to grow by $3.5 \%$ and $4.0 \%$ during the corresponding period (NFP, 2011).

\section{Production process of mulberry sericulture in northwest India}

In northwest India, fast urbanization due to demographic expansion has reduced agricultural acreage and have forced "mulberry" to exist only on the boundaries of agriculture field (Fig. 1a). The whole process of mulberry sericulture (Fig. 2) is divided in to pre-cocoon and post-cocoon sector. Management of mulberry trees and conducting indoor silkworm rearing to produce silk cocoon is on-farm activity in pre-cocoon sector, whereas reeling, dying and weaving are off-farm activity of post-cocoon sector. During silkworm's rearing, B. mori passes through four molts and five larval stages, whereat maximum feeding is taken place in fifth stage. Under ideal conditions, $B$. mori completes cocoon formation in 24-28 days; however, this period may vary due to fluctuations in indoor temperature and relative humidity. 


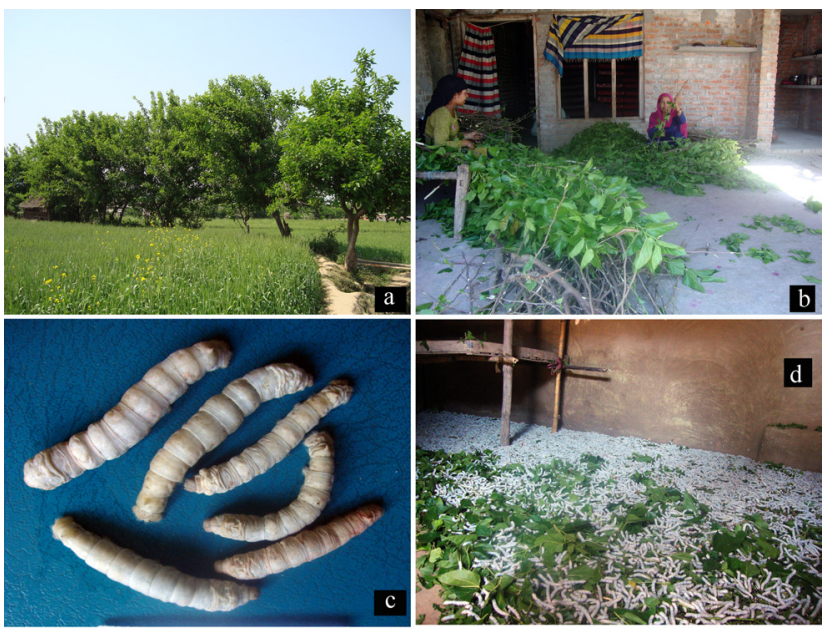

Fig. 1. a) Sericulture system in northwest India; b) Lopping of mulberry twigs for silkworm feeding; c) Diseased larvae by Grasserie diseases; d) Constraints of rearing appliances leads to space problem.

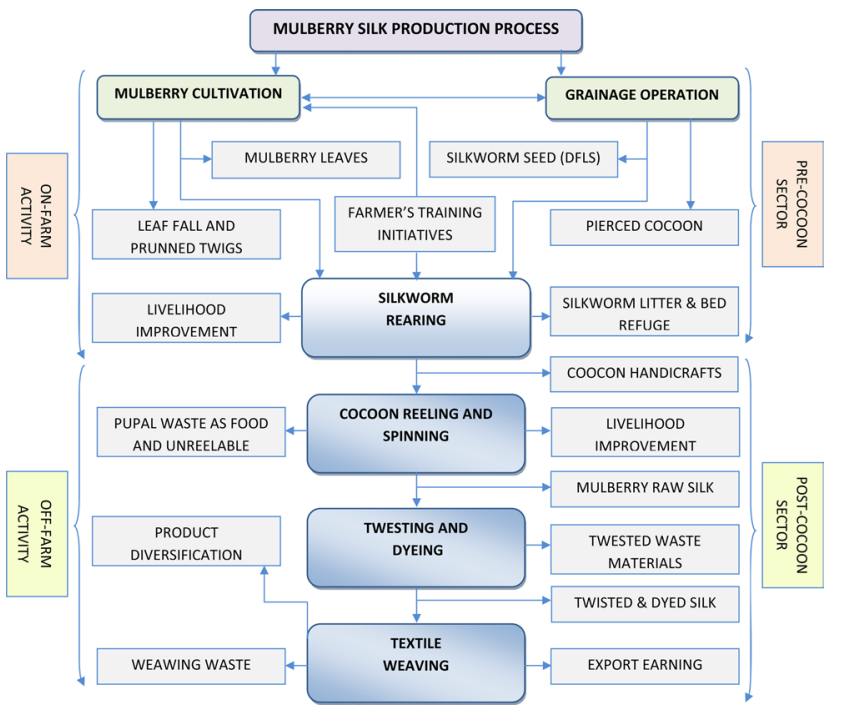

Fig. 2. Mulberry silk production.

\section{Materials and Method}

\section{Study context}

The study was conducted in five non-traditional silk producing states of India comprising, Himachal Pradesh, Punjab, Rajasthan, Uttarakhand, and Uttar Pradesh. The climate of Himachal Pradesh and Uttarakhand suits for production of quality bivoltine silk. However, in Uttar Pradesh, Punjab and Rajasthan, both bivoltine and multi-bivoltine breeds are reared. In Himachal
Pradesh, sericulture is practiced in the districts of Hamirpur, Bilaspur, Mandi, Kangra, Shimla, Solan, Sirmaur, and Una. In Uttar Pradesh, mulberry sericulture exists in 46 districts with maximum mulberry acreage in Saharanpur (87.0 ha) followed by Kushinagar (50.58 ha) and Bahraich (40.46 ha). There are 39 state sericulture farms with 485.62 ha of mulberry in Uttar Pradesh and four-crop schedule is followed for commercial silkworm rearing (DOS, 2013). In Rajasthan, mulberry sericulture is practiced in Udaipur, Banswara, Sirohi and Kota with integration of Central Silk Board (CSB) and Tribal Area Development Authorities (TADA). In Punjab, sericulture activities have been initiated in Sujanpur, Pathankot, and Gurdaspur with total mulberry area of 608 ha with 475 farmers. Uttarakhand state has congenial climatic conditions for bivoltine mulberry silk, and there are 69 state sericulture farms with 475 farmers.

\section{Data collection}

Data on mulberry area and silk production during $11^{\text {th }}$ plan period (April 2007 to March 2012) was collected from different reports of the Central Silk Board, Ministry of Textiles, Government of India. We used Microsoft Office Excel 2007 to calculate annual linier growth rate (LGR) on three variables of sericulture progress viz., mulberry area, total raw silk production, and per hectare raw silk productivity. Information about moriculture (cultivation of mulberry) practices, silkwormcropping patterns, implementation of improved rearing technology, reared silkworm's breed, occurrence of silkworm disease and process of cocoon marketing etc. were collected during field visits through one-to-one interactions with the farmers and officials of concerned department of sericulture. Data on state wise silk production, silkworm breeds reared, and their productivity at farmer's level was collected from concerned department of sericulture in the respective states.

\section{Statistical analysis}

Statistical analysis of the data was carried out with the help of statistical software "STATISTICA" developed by the Stat Soft Inc, 2300 East 14th Street, Tulsa, UK. We employed descriptive statistics and frequency analysis to analyze most of the data. One-way ANOVA was used to test the significance of difference 


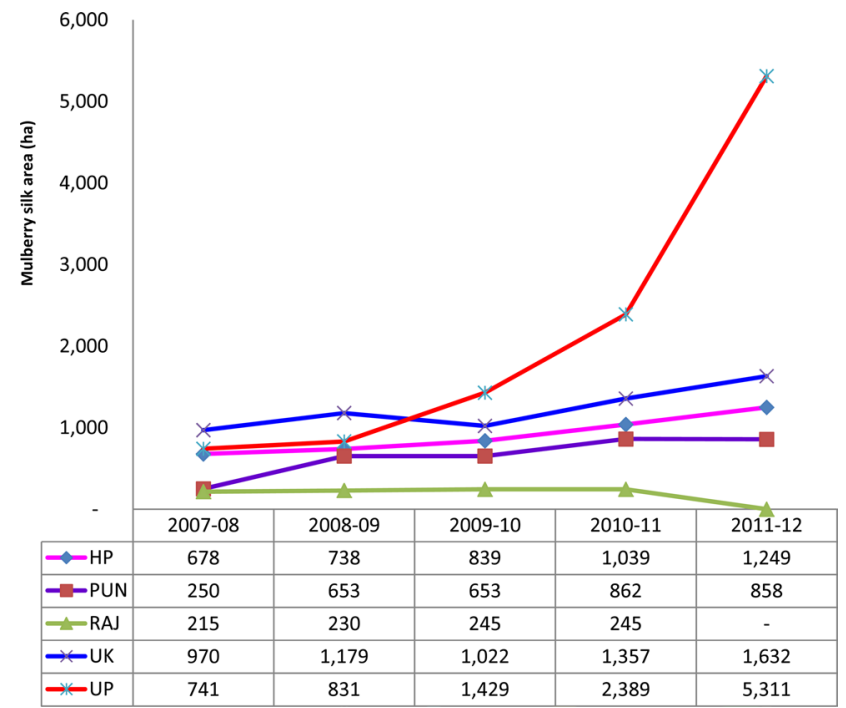

Fig. 3. Mulberry area (ha) in nontraditional states of northwest India during 11th plan period.

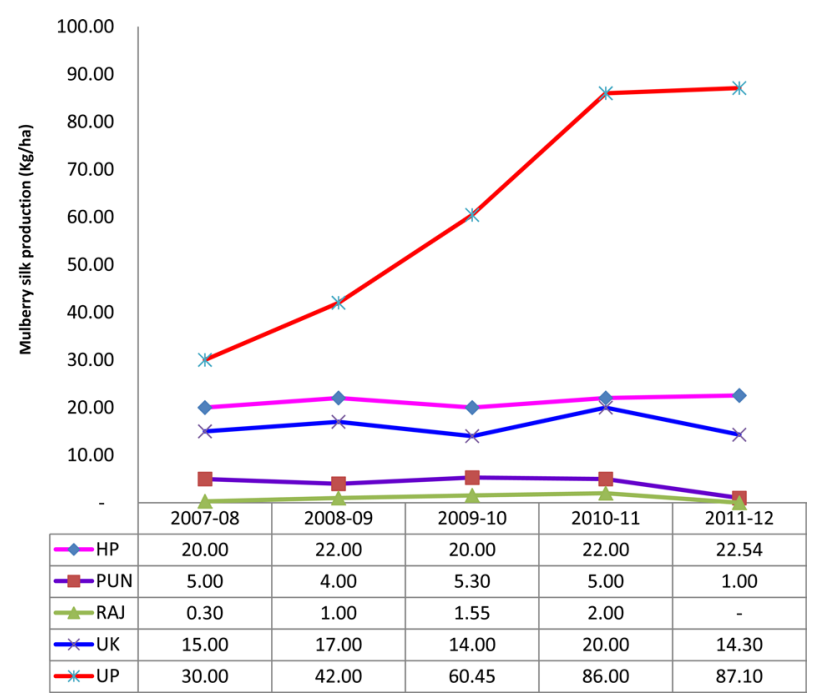

Fig. 4. Mulberry silk production in nontraditional states of northwest India during 11th plan period.

in means of the variables. The level of significance for the study was fixed at 0.05 . Post HOC test was carried out by using Tukey's HSD test to compare the homogeneous pairs of means.

\section{Results}

Mulberry silk in India is produced in twenty-six states that are grouped into traditional and non-traditional states. Data presented at Table 1 indicates that non-traditional states contribute $19.10 \%$

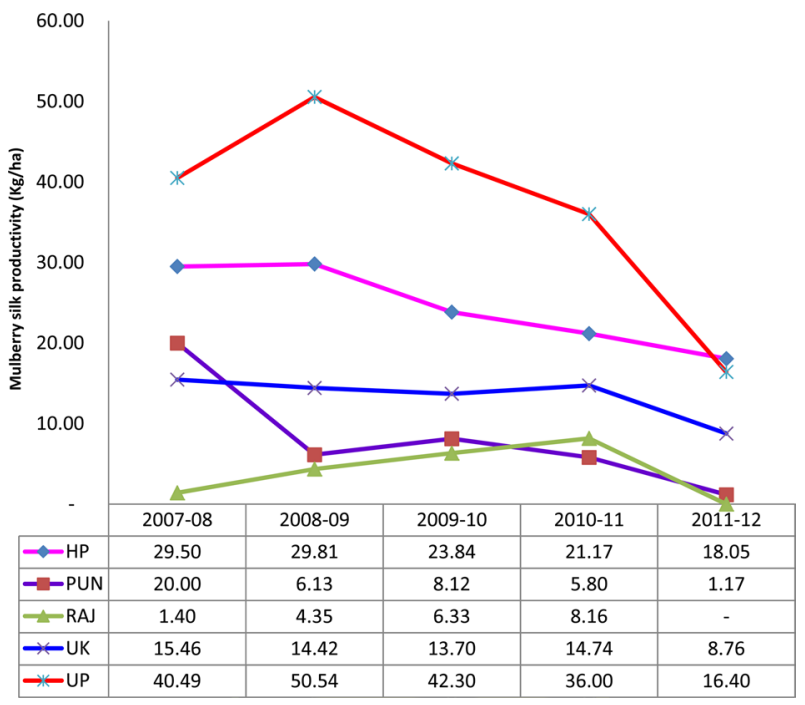

Fig. 5. Mulberry silk productivity in nontraditional states of northwest India during 11th plan period (April, 2002 to March, 2012).

(34,585 ha) of the total mulberry acreage (181,089 ha), but share only $3.0 \%$ (555 MT) of the total mulberry raw silk production $(18,272 \mathrm{MT})$. This disproportion in mulberry area vis-a-vis silk production subsisted due to high difference of $753.67 \%$ (104.88 $\mathrm{Kg}$ ) in per hectare raw silk productivity between the traditional silk producing state $(120.93 \mathrm{~kg} / \mathrm{ha})$ and non-traditional silk producing states (16.05 kg/ha) (Table 1). Fig 3, 4, and 5 shows that sericulture progress in northwest India have been very slow and quite uneven.

In $U P$, there has been a substantial increase of $617 \%$ (4570 ha) and $190.33 \%$ (57.10 MT) in mulberry area and raw silk production at annual linear growth rate of $63.62 \%$ and $30.53 \%$, respectively; however, silk productivity, which was $40.49 \mathrm{Kg} / \mathrm{ha}$ in 2007 reduced to $16.40 \mathrm{Kg} / \mathrm{ha}$ in 2012 with annual linear growth rate of $-20.22 \%$ (Table 1). Similarly in Himachal Pradesh, in spite of $84.21 \%$ (571 ha) increase in mulberry acreage at annual linear growth rate of $16.50 \%$, raw silk production could increase only by $12.7 \%(2.54 \mathrm{MT})$ at annual linear growth rate of $3.03 \%$ due to $38.81 \%(11.45 \mathrm{~kg} / \mathrm{ha})$ decrease in raw silk productivity at annual linear growth rate of $-11.56 \%$. In Punjab, there was an addition of $243.2 \%$ (608 ha) in mulberry acreage between 2007 to 2012 at annual linear growth rate of $36.11 \%$, but raw silk production and productivity, both reduced sharply to negligible figure at annual linear growth rate of $-33.13 \%$ and $-50.87 \%$, respectively. Similarly in Rajasthan, mulberry area, raw silk production and productivity, all reduced to negligible figures. In Uttarakhand, there has been $68.24 \%$ (662 ha) increase in mulberry acreage during 2007-12, 
Table 2. Descriptive statistics and ANOVA on mulberry area, silk production and productivity in northwest India during 11th plan period (2007-2012)

\begin{tabular}{|cccc|}
\hline State & $\begin{array}{c}\text { Mulberry } \\
\text { Area (ha) }\end{array}$ & $\begin{array}{c}\text { Silk Produc- } \\
\text { tion (MT) }\end{array}$ & $\begin{array}{c}\text { Silk produc- } \\
\text { tivity (kg/ha) }\end{array}$ \\
\hline H.P. & $\begin{array}{c}908.60 \\
(104.88)\end{array}$ & $21.31(0.54)$ & $24.47(2.30)$ \\
\hline PUN. & $\begin{array}{c}655.20 \\
(111.37)\end{array}$ & $4.06(0.79)$ & $8.24(3.15)$ \\
\hline RAJ. & $\begin{array}{c}187.00 \\
(38.44)\end{array}$ & $0.97(0.30)$ & $4.05(1.23)$ \\
\hline U.K. & $1,232.00$ & $16.06(1.11)$ & $13.42(1.19)$ \\
\hline U.P. & $\begin{array}{c}(120.66) \\
(845.38)\end{array}$ & $61.11(11.46)$ & $37.15(5.69)$ \\
\hline Grand mean & $1,024.60$ & 20.70 & 17.47 \\
\hline SE of Mean & 203.14 & 4.78 & 2.72 \\
\hline Error DF & 20 & 20 & 20 \\
\hline F & 3.542 & 21.69 & 17.45 \\
\hline P $(0.05)$ & 0.024 & 0.000000 & 0.000003 \\
\hline
\end{tabular}

Figures in parenthesis are standard error of mean

but this physical progress in mulberry acreage could not commensurate with improvement in silk production and productivity, rather it declined at annual linear growth rate of $-1.19 \%$ and $-13.24 \%$, respectively. In northwest India, during $11^{\text {th }}$ plan period (2007-2012), there was an addition of 6196 ha (217.09\%) in mulberry acreage at annual linear growth rate of $33.44 \%$; however, total silk production could increase only by $54.64 \mathrm{MT}$ (78.57\%) at annual linear growth rate of $15.59 \%$ due to $43.93 \%$ (10.82 kg/ha) reduction in raw silk productivity at annual linear growth rate of $-13.46 \%$. Now, average raw silk productivity of northwest India remains at $13.81 \mathrm{~kg} / \mathrm{ha}$, which is lower by $452.93 \%(76.36 \mathrm{~kg})$ in comparison to the national average of $100.90 \mathrm{~kg} / \mathrm{ha}$.

Further, Descriptive statistics on progress of sericulture in northwest India indicated higher consistency in term of silk productivity than mulberry acreage and silk production (Table 2). Null hypothesis $\left(\mathrm{H}_{0}\right)$ for no difference in all the variables was rejected by ANOVA. Tukey's HSD test presented at Table 3 indicated that average mulberry acreage of Uttar Pradesh (2140.20 ha) and Rajasthan (187 ha) differ significantly. Secondly, raw silk production of Uttar Pradesh (61.11 MT) differed significantly with all other states of northwest India, however, other pairs of means on raw silk production were found homogenous. Third, average raw silk productivity of Uttar Pradesh $(37.15 \mathrm{~kg} /$ ha) differed significantly with the productivity of Uttarakhand (13.42 kg/ka), Punjab (8.24) and Rajasthan (4.05); however silk productivity of Uttarakhand, Punjab and Rajasthan was found homogeneous. Similarly, there was no any significant difference in the mean raw silk productivity of Himachal Pradesh and Uttarakhand and between Uttar Pradesh and Himachal Pradesh.

\section{Discussion}

Agricultural land holdings in northwest India are generally used to grow cereals and vegetables for domestic consumption and marketing. Sericulture farmers in northwest India normally

Table 3. Tukey HSD test for Homogenous Groups

\begin{tabular}{|c|c|c|c|c|c|c|c|c|c|c|}
\hline \multicolumn{4}{|c|}{$\begin{array}{l}\text { Variable: Mulberry area, Alpha }=0.05000, \text { Error: } \\
\text { Between MS }=7549 E 2, \text { df }=20.000\end{array}$} & \multicolumn{3}{|c|}{$\begin{array}{l}\text { Variable: Silk production, Alpha }= \\
\begin{array}{l}0.05000, \text { Error: Between } \\
M S=133.73, \text { df }=20.000\end{array}\end{array}$} & \multicolumn{4}{|c|}{$\begin{array}{c}\text { Variable: Silk productivity, Alpha }=0.05000 \\
\text { Error: Between MS }=51.411, \text { df }=20.000\end{array}$} \\
\hline State & $\begin{array}{c}\text { Mulberry Area } \\
\text { Mean }\end{array}$ & 1 & 2 & Production Mean & 1 & 2 & $\begin{array}{l}\text { Silk Productivity } \\
\text { Mean }\end{array}$ & 1 & 2 & 3 \\
\hline RAJ & 187.00 & 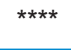 & & 0.97 & $* \star \star *$ & & 4.05 & $* * * *$ & & \\
\hline PUN & 655.20 & $* * * *$ & $* \star \star *$ & 4.06 & $* * * *$ & & 8.24 & $* * * *$ & & \\
\hline UK & 1232.00 & $* \star * *$ & $* \star * *$ & 16.06 & $* \star * *$ & & 13.42 & $* * * *$ & $* * * *$ & \\
\hline $\mathrm{HP}$ & 908.60 & $* * * *$ & $* * * *$ & 21.31 & $* * * *$ & & 24.47 & & $* * * *$ & $* * * *$ \\
\hline UP & 2140.20 & & $* * * *$ & 61.11 & & $* * * *$ & 37.15 & & & $* * * *$ \\
\hline
\end{tabular}


Table 4. Seasonal variation in cocoon productivity of Uttarakhand

\begin{tabular}{|ccccccc|}
\hline & \multicolumn{3}{c}{ Spring season } & & Autumn season \\
\cline { 2 - 7 } Year & $\begin{array}{c}\text { DFLs reared } \\
\text { (Number) }\end{array}$ & $\begin{array}{c}\text { Cocoon } \\
\text { Production (Kg) }\end{array}$ & $\begin{array}{c}\text { Cocoon } \\
\text { Productivity } \\
\text { (Kg/100 Dfils) }\end{array}$ & $\begin{array}{c}\text { DFLs reared } \\
\text { (Number) }\end{array}$ & $\begin{array}{c}\text { Cocoon } \\
\text { Production (Kg) }\end{array}$ & $\begin{array}{c}\text { Cocoon } \\
\text { Productivity } \\
\text { (Kg/100 Dils) }\end{array}$ \\
\hline $2005-06$ & $142,617.00$ & $62,266.00$ & 43.66 & $137,800.00$ & $32,762.00$ & 23.78 \\
\hline $2006-07$ & $143,350.00$ & $46,593.00$ & 32.50 & $139,000.00$ & $35,334.00$ & 25.42 \\
\hline $2007-08$ & $146,920.00$ & $42,869.00$ & 29.18 & $142,800.00$ & $31,993.00$ & 22.40 \\
\hline $2008-09$ & $148,625.00$ & $46,037.00$ & 30.98 & $133,000.00$ & $14,820.00$ & 11.14 \\
\hline $2009-10$ & $144,000.00$ & $42,251.00$ & 29.34 & $183,000.00$ & $40,185.00$ & 21.96 \\
\hline Mean & $\mathbf{1 4 5 , 1 0 2 . 0 0}$ & $\mathbf{4 8 , 0 0 3 . 0 0}$ & $\mathbf{3 3 . 0 8}$ & $\mathbf{1 4 7 , 1 2 0 . 0 0}$ & $\mathbf{3 1 , 0 1 9 . 0 0}$ & $\mathbf{2 1 . 0 8}$ \\
\hline St. Error & $\mathbf{1 , 1 4 4 . 0 2}$ & $\mathbf{3 , 6 6 5 . 5 8}$ & $\mathbf{2 . 7 0}$ & $\mathbf{9 , 1 0 5 . 5 1}$ & $\mathbf{4 , 2 9 5 . 5 2}$ & $\mathbf{2 . 5 2}$ \\
\hline
\end{tabular}

Source: Directorate of sericulture, Uttarakhand (2011) * Dfls stands for disease free layings of mulberry silkworm, 1 Dfls is equal to $450-500$ eggs

use bunds of their agriculture field to raise mulberry tree (Fig. 1). Mulberry trees grown on the field boundaries are not governed by any manuring or pruning schedule, which reduces optimum leaves production efficiency that affects cocoon productivity. Secondly, during the course of silkworm rearing, farmers normally lop the whole branch of mulberry (Fig. 1b) and takes out all the leaves from top to bottom to feed the silkworms twice or thrice in twenty four hrs by escaping one or two feeding. Lopping of mulberry twigs reduces the prospect of leaf availability in the next crop and irregular feeding affects the cocoon productivity and increases yield gaps. Third, in northwest India, spring rearing, which is the main crop, is completed by fifth of April and mulberry tree attains full flush by end of May, but farmers neither take any silkworm crop in May, nor do they prune mulberry tree in last week of June as recommended. The sprouted leaves in May-June become very coarse and develop leaf spot disease by the beginning of autumn crop in September, which is the secondary crop in Northwest India. The deteriorated leaves quality reduces the cocoon productivity in autumn and increases the percentage of crop losses due to silkworm diseases. Gram Panchayats, under different government schemes like Mahatma Gandhi National Rural Employment Guarantee Act (MGNREGA), Swarnajayanti Gram Swarojgar Yojana (SGSY), Greening rural development (Greening RD), and Council for Advancement of People's Action and Rural Technology (CAPART) etc. may undertake plantation of improved mulberry variety on panchayat and forestry land to increase the availability of mulberry leaves. Further, farmers may be educated for leaf plucking instead of lopping the mulberry twigs.

In northwest India, there exist only two-silkworm crop schedule due to climatic restriction except to Uttar Pradesh, where four-crop schedule is being followed. Stabilized spring crop is the main crop with higher productivity and autumn crop is the secondary crop with low productivity. For example, in Uttarakhand, cocoon productivity of spring crop $(33.08 \mathrm{Kg} / 100$ disease free layings) is $60.34 \%$ higher than the productivity of autumn (21.08 kg/100 disease free layings), but average demand of Dfls (disease free layings of silkworm) in both the seasons is almost same (Table 4). Interestingly, availability of mulberry leaves is double in autumn crop than the spring rearing. Therefore, by increasing the quantum of rearing in spring season, cocoon production and productivity, both can be increased; however, to achieve this, availability of mulberry leaves for spring rearing is to be increased. The existing pruning schedule may be adjusted according to the changing climate, besides application of recommended manure and fertilizers by the farmers to increase the availability of mulberry leaves for enhanced Dfls intake in spring rearing.

The available bivoltine breeds for northwest India are comparatively more suitable for spring rearing, but in summer, they succumb to different diseases. It is observed that ruling hybrid SH6 x NB4D2 is now showing some problem of disease susceptibility in the final stage worms on $5^{\text {th }}$ day onwards. On the other hand, new developed hybrid Dun6 x Dun22 is not being taken up at farmer's level in larger quantity, beside its proved potential. Further, CSR breeds are being taken up in spring as 
Table 5. Average productivity of major silkworm hybrids in Uttarakhand (Kg cocoons /100 Dfls)

\begin{tabular}{|ccccc|}
\hline \multirow{2}{*}{ Year } & \multicolumn{2}{c}{ CSR Hybrid } & \multicolumn{2}{c|}{ SH6XNB4D2 } \\
\cline { 2 - 5 } & $\begin{array}{c}\text { Spring } \\
\text { Rearing }\end{array}$ & $\begin{array}{c}\text { Autumn } \\
\text { Rearing }\end{array}$ & $\begin{array}{c}\text { Spring } \\
\text { Rearing }\end{array}$ & $\begin{array}{c}\text { Autumn } \\
\text { Rearing }\end{array}$ \\
\hline $2002-03$ & 32.71 & 14.06 & 30.7 & 18.5 \\
\hline $2003-04$ & 33.74 & - & 38.17 & 25.83 \\
\hline $2004-05$ & 28.32 & 22.5 & 29.97 & 23.86 \\
\hline $2005-06$ & 45.93 & - & 40.99 & 23.78 \\
\hline $2006-07$ & 35.16 & - & 28.67 & 25.42 \\
\hline $2007-08$ & 29.18 & - & - & 22.4 \\
\hline $2008-09$ & 30.98 & - & - & 11.23 \\
\hline $2009-10$ & 37.36 & 22.88 & 24.06 & 20.97 \\
\hline Mean & $\mathbf{3 4 . 1 7}$ & $\mathbf{7 . 4 3}$ & $\mathbf{2 4 . 0 7}$ & $\mathbf{2 1 . 5 0}$ \\
\hline St. Error & $\mathbf{2 . 2 8}$ & $\mathbf{4 . 1 8}$ & $\mathbf{6 . 3 5}$ & $\mathbf{1 . 8 9}$ \\
\hline
\end{tabular}

well as in autumn; however, it is known that CSR breeds require good rearing conditions and quality leaves for expression on their full potential. In a case study, impact of promising silkworm breeds on cocoon productivity in Uttarakhand is analyzed (Table 5) and it is found that in spring crop, both CSR breeds and SH6 $\mathrm{X}$ NB4D2 have performed at par with an average productivity of $34.17 \mathrm{Kg} / 100 \mathrm{DFLs}$ and $32.09 \mathrm{Kg}$, respectively; however, in autumn crop the performance of SH6 x NB4D2 is quite better then the CSR hybrids, and $<90 \%$ of total cocoons production is contributed by SH6 x NB4D2. From these observations, it can be construed that in autumn crop, ruling hybrid SH6 $\mathrm{x}$ NB4D2 can be preferred over CSR breeds. Furthermore, autumn specific hybrids that can sustain high pathogen load may be evolved through directional breeding programmes and sturdy silkworm breeds that could tolerate high temperature and low humidity could be developed to increase the remunerability of sericulture in northwest India by adding one more crop in MayJune. Workable technology to harvest and preserve the quality mulberry leaves in summer season will also be required.

Success and profitability of silkworm rearing primarily rely on quality of seed being the basic input, and the quality of mulberry leaves. However, most vitally, the disease component occupies a prime importance, because in autumn crop, the incidence of silkworm diseases (Fig. 1c) is as high as $35-100 \%$ in northwest
India that reduces the viability of sericulture. As a ground reality, the silkworm rearing practices in the rural areas are not full proof for prevention of diseases, as silkworms are reared in the rearing cum dwelling houses and most of them are unhygienic, badly ventilated, dark, and damp helping in pathogen survival. It is also observed that many of the farmers do not follow disinfection procedures effectively and Secondly, many of the farmers are not self-sufficient with rearing appliances like rearing trays, cleaning nets, mountages etc, and their borrowing from other farmers leads to contamination. Third, farmers do not regularly pick up the diseased larvae or even if they pick them up, they do not discard them, rather they are rear in a separate tray that leads to cross contamination. In some cases, farmers disposed off the diseased worms haphazardly near the dwelling places, which are then picked up by birds and pathogens are disseminated all around area including mulberry trees with their faeces. All these factors lead to disease contamination and cocoon yield is adversely affected. Presently, disinfection measure along with maintenance of hygiene is the only way to contain all types of silkworm diseases, because there is no curative treatment for any of the silkworm diseases and they are best prevented than cured. However, problem lies with the pathogens that gain entry into the rearing environment during the course of rearing and pathogen load is increased tremendously from one crop to another. It is therefore imperative to develop a cost-effective innovative technology to lower down the losses from silkworm disease at farmer's level, especially for autumn crop, otherwise, failure of crop or low realization from silkworm rearing may divert the mind and spirit of farmers, incurring an irreversible loss to the sericulture industry in northwest India.

Development of cost effective technologies suitable to the local environment and socioeconomic conditions of the farmers is prerequisite for mulberry sericulture. It is found that most of the farmers in northwest India are not self-sufficient with rearing appliances and space to carry out silkworm rearing as per the recommended packages. Farmers follow floor rearing with crowded worm's population in poor hygiene (Fig. 1d) that leads to disease outbreak. Crowded worm population per unit area dissolves many of the impacts of improved rearing technology and extension efforts.

In northwest India, feasibility of shoot rearing from tree mode of plantation should be explored out, which will not only solve the space constraints by spreading silkworm population 
in different tiers on mulberry twigs, but will also reduce loss of mulberry leaves and negative impact of missing feedings. Further, mortality during spinning stage due to improper mounting is also a cause for low cocoon production in northwest India. Improper mounting leads to $13-18 \%$ cocoons loss. Rotary mountages may be introduced in the field to reduce the cocooning losses and farmers should be properly trained for mounting and rotation of the mountages.

Participatory approach for technology transfer has shown promising results in agriculture sector, which can also be tried in sericulture sector. Lead farmer concept, training of at least five unemployed youth from every sericulture cluster, linkage of Krishi Vigyan Kendras (KVKs) of Indian Council of Agricultural Research (ICAR) with sericulture cluster, establishment of farmer field school are some of the other viable options for smooth transfer the improved sericulture technologies to the farmers for reducing existing yield gap. Marketing system of silk cocoon is not adequately systematic in northwest India and farmers are not getting competitive pricing of cocoon like traditional state. Several state departments in northwest India have evolved auction method of cocoon marketing, but many farmers have questioned about business transparency.

In northwest India, the state owned government sericulture farms heavily support farmer's silkworm rearing by providing mulberry leaves. However, some people argue that these farms are not maintained to their installed capacity. Further, mulberry is a heavy feeder that replace huge nutrients base from soil, and application of soil nutrients are not properly monitored some tine. Soil profile of sericulture areas and state owned sericulture farms needs to be calibrated to apply test-based nutrients to improve soil health. Proper maintenance of the government sericulture farms is the basic requisite to turn out alternative sericulture of northwest India into a substantive sericulture.

According to Forest (Conservation) Act 1980, plantation of mulberry in forest area for silkworm rearing is not a forestry activity. Ministry of Environment and Forest may be perused to include plantation of mulberry tree in various agroforestry schemes under Forests (Conservation) Act, 1980 in northwest India. This will improve the livelihood delivery of forest to the poor people in forested area. And for this purpose, existing 106,479 Joint Forest Management Committees (JFMCs) in 28 states that are managing $22.02 \mathrm{~m}$ ha forest (Planning Commission, 2011) can be integrated with respective department of sericulture to realize benefits of forest-based sericulture under collaborative forest management and concomitantly foster its impact on incentive linked forest management initiatives.

\section{Conclusion}

Constraints in taking more than two crops in a year, shortage of quality mulberry leaves, revalidation of pruning and brushing schedule, development of thermo tolerant silkworm breeds, improvement in rearing technologies, disinfection and hygiene, disease management aspect, transfer of improved sericulture technology, evolving market linkages, policy decision to include mulberry in Forest (Conservation) Act 1980, etc are some of the vital issues, which requires proper attention from the sericulture research and development sector to reduce yield gap at farmer's level and to make sericulture a profitable business in northwest India. Sericulture will sustain automatically if productivity per unit area of land is increased, and this can only happen, if existing constraints are removed are at least lowered down.

\section{Acknowledgement}

We wish to thank anonymous reviewers for their insightful comments they made on the drafts of this article. We thank Dr. Mukhtar Ahmad and Mr. R. S. Bhandari for their suggestions in preparation of manuscript and Directorate of Sericulture, Uttarakhand for providing sericulture data. We take full responsibility for any errors or omissions that might remain in the finished product.

\section{References}

Gautam HR, Bhardwaj ML (2013). New arenas in rural employment. Kurukshetra 61(4), 8-11.

Kumaresan P, Srinivasa G, Vijaya Prakash NB (2005). Productivity and Profitability in Rainfed Sericulture - A Study in the District of Chamaraja Nagar in Karnataka. Agricultural Economics Research Review 18, 91-102. http://ageconsearch.umn.edu/bitstream/58414/2/ P-Kumaresan.pd

Lakshmanan S, Mallikarjuna B, Jayaram H, Ganapathy RR, 
Subramanian MR et al. (1996). Economic issues of production of mulberry sericulture in Tamilnadu-Micro-economics study. Indian Journal of Sericulture 35(2), 128-131.

Lakshmanan S (2007). Yield gaps in mulberry sericulture in Karnataka: An econometric analysis. Indian Journal of Agricultural Economics, $62(4), 623$.

Prakash NBV, Dandin SB (2005). Yield gaps and constraints in bivoltine cocoon production in Mandya district of Karnataka- an economic analysis. Indian Journal of Sericulture 44(1), 50-54.

Raveendra M, Iyengar MNS., Chikkanna, Datta RK (1997). Seasonal, spatial and temporal performance of sericulture in Hassan district, Karnataka. Indian Journal of Sericulture 36(2), 106-110.

Raveendra M, Veerabhadrappa BP, Renukarya CK (2009). Yield gap in sericulture in Karnataka - an economic analysis. Karnataka Journal of Agricultural Sciences 22 (5), 1046-1050.

Ravindran N, Anita SB, Elangovan S (1993). Sericulture: A profitable farm venture. Agricultural Situation in India 18 (3), 23-26.

Sinha SS, Prasad BC, Ghosh S (1985). Sericulture extension in nontraditional areas. Indian Silk, 34(3), 36-38.

C.S.B. (2012). Why Sericulture. Central Silk Board, Ministry of Textiles, Government of India, Bangalore, India. http://www.csb.gov. in/silk-sericulture/sericulture.

N.F.P. (2013). National Fibre Policy 2010-11. Ministry of Textiles Government of India, Delhi, India. http://texmin.nic.in/policy/Fibre Policy_dir_mg_d_20100608.pdf.

D.O.S. (2013). Directorate of sericulture, Uttar Pradesh. http:// sericulture.up.nic.in/downloads.htm.

Planning Commission, 2011. Rapid Poverty Reduction: Eleventh Five Year. Planning Commission, Government of India, New Delhi. http:// planningcommission.nic.in/plans/planrel/fiveyr/11th/11_v3/11v3 ch4.pdf. 